\title{
Potential for Protein Kinase Pharmacological Regulation in Flaviviridae Infections
}

\author{
Ana-Belén Blázquez *(i) and Juan-Carlos Saiz \\ Department of Biotechnology, Instituto Nacional de Investigación y Tecnología Agraria y Alimentaria (INIA), \\ 28040 Madrid, Spain; jcsaiz@inia.es \\ * Correspondence: blazquez@inia.es
}

Received: 9 October 2020; Accepted: 14 December 2020; Published: 15 December 2020

\begin{abstract}
Protein kinases (PKs) are enzymes that catalyze the transfer of the terminal phosphate group from ATP to a protein acceptor, mainly to serine, threonine, and tyrosine residues. PK catalyzed phosphorylation is critical to the regulation of cellular signaling pathways that affect crucial cell processes, such as growth, differentiation, and metabolism. PKs represent attractive targets for drugs against a wide spectrum of diseases, including viral infections. Two different approaches are being applied in the search for antivirals: compounds directed against viral targets (direct-acting antivirals, DAAs), or against cellular components essential for the viral life cycle (host-directed antivirals, HDAs). One of the main drawbacks of DAAs is the rapid emergence of drug-resistant viruses. In contrast, HDAs present a higher barrier to resistance development. This work reviews the use of chemicals that target cellular PKs as HDAs against virus of the Flaviviridae family (Flavivirus and Hepacivirus), thus being potentially valuable therapeutic targets in the control of these pathogens.
\end{abstract}

Keywords: protein kinases; phosphorylation; antivirals; flaviviruses; hepatitis C virus

\section{Introduction}

Kinases are a group of enzymes that catalyze the transfer of the terminal $\gamma$-phosphate from ATP to the hydroxyl group of an acceptor substrate, thus participating in a huge variety of cellular processes, such as proliferation, apoptosis, metabolism, transcription, or antibiotic resistance, among others. These phosphorylation reactions can be reversed by the corresponding phosphatases. These important discoveries concerning reversible protein phosphorylation as a biological regulatory mechanism were recognized by the award of the Nobel Prize in Physiology or Medicine in 1992 to Edmond H. Fischer and Edwin G. Krebs [1]. Even though all kinases catalyze the same phosphoryl transfer reaction, there is a wide diversity in their structures and substrates [2], which include proteins, lipids, carbohydrates, amino acids, vitamins, and cofactors. According to their structure and sequence, kinases have been classified into 30 families [3], of which the protein kinase (PK) family is the largest comprising one of the most abundant protein families in mammalian genomes [4].

PKs catalyze protein phosphorylation, mainly of serine, threonine, and tyrosine residues, and play a critical role in cellular signaling pathways that affect crucial cell processes, such as growth, differentiation, and metabolism [5]. Phosphorylated proteins can initiate a downstream cascade of reactions, resulting in a vast range of responses including activation or inhibition of enzyme activities [6], changes in biological activity, as well as facilitating or perturbing movement between subcellular compartments, and initiating or interrupting protein-protein interactions [7].

PK activity was first observed in 1954 in an enzyme that catalyzed casein phosphorylation [8]. The first evidence that one PK can activate another was the observation that cAMP-dependent protein kinase A (PKA) activates phosphorylase kinase [9]. The same kinase, PKA, was also described as the first example of enzyme inhibition by phosphorylation, which inhibits glycogen synthase [10]. 
Since then, characterization of PKs has been widely addressed. In 2002, Manning et al. [11] published the PK complement of the human genome, the so-called kinome, classifying it in 518 members, with most PKs (478) belonging to a single superfamily containing a eukaryotic PK (ePK) catalytic domain, while the other 40 PK genes were reported to belong to a few atypical families (aPK) with proteins showing biochemical kinase activity, but with no sequence similarity to the ePK domain. According to sequence comparison of their catalytic domains, the human kinome was classified into nine different phylogenetic groups for ePKs (Table 1) and four groups for aPKs (Table 2).

Table 1. Classification of eukaryotic protein kinases (ePKs).

\begin{tabular}{cl}
\hline Group & \multicolumn{1}{c}{ Representative Families of the Group } \\
\hline AGC & $\begin{array}{l}\text { PKA (cAMP-dependent protein kinase), PKC (protein kinase C), PKG } \\
\text { (cGMP-dependent protein kinase), PKN (protein kinase N), AKT } \\
\text { (protein kinase B) }\end{array}$ \\
\hline $\begin{array}{c}\text { CAMK (Calcium Calmodulin } \\
\text { dependent kinase) }\end{array}$ & $\begin{array}{l}\text { PhK (phosphorylase kinase), CAMK (Ca2+/calmodulin-dependent } \\
\text { protein kinase), MAPKAPK (mitogen-activated protein kinase-activated } \\
\text { protein kinase), MLCK (myosin light-chain kinase) }\end{array}$ \\
\hline CK1 (Casein Kinase 1) & TTBK (tau-tubulin kinase), VRK (vaccinia-related kinase) \\
\hline CMGC & $\begin{array}{l}\text { CDK (cyclin-dependent kinase), MAPK (mitogen-activated protein } \\
\text { kinase), GSK (glycogen synthase kinase), CDKL (cyclin Dependent }\end{array}$ \\
\hline Kinase Like), JNK (c-Jun N-terminal kinase), p38
\end{tabular}

Table 2. Classification of atypical protein kinases (aPKs).

\begin{tabular}{cl}
\hline Group & \multicolumn{1}{c}{ Representative Families of the Group } \\
\hline alpha & $\begin{array}{l}\text { ChaK (Channel kinase), eEF2K (Eukaryotic elongation } \\
\text { factor 2 kinase) }\end{array}$ \\
\hline PIKK (phosphatidyl inositol 3' kinase-related kinase) & $\begin{array}{l}\text { ATM (Ataxia telangiectasia mutated kinase), ATR (Ataxia } \\
\text { telangiectasia and Rad3 related kinase), FRAP, SMG1 } \\
\text { (Nonsense Mediated MRNA Decay Associated PI3K Related Kinase) }\end{array}$ \\
\hline PDHK (pyruvate dehydrogenase kinase) & PHDK (pyruvate dehydrogenase kinase), BKCDK \\
\hline RIO (right open reading frame) & $\begin{array}{l}\text { RIOK (Right open reading frame protein kinase), SUDD (Right open } \\
\text { reading frame protein kinase3) }\end{array}$ \\
\hline
\end{tabular}

All PKs contain a conserved catalytic core comprised of two lobes ( $\mathrm{N}$ and $\mathrm{C}$ ) located, respectively in the N- and C-terminal position of this domain. They may also contain additional, family-specific domains, which can be $\mathrm{N}$ - and/or C-terminal to the kinase domain. The N-lobe binds and orientates ATP, and the $\alpha$-helical C-lobe is essential for substrate binding and phosphoryl transfer initiation [12]. An active-site cleft containing the ATP-binding site is placed between the two lobes [13]. Although the catalytic core can vary in terms of length and sequence among the different PKs, the residues involved in the catalysis are highly conserved [12]. These differences in the catalytic core influence the way in which substrates interact with kinase, thus determining the specificity of kinase-substrate interactions [14]. 
PKs can exist in an active or an inactive state, and, in many cases, phosphorylation is required for full enzymatic activity. The mechanisms of activation and deactivation are diverse and kinase specific $[15,16]$. In the active state, all kinases show a similar conformation, however, several differences are observed between inactive states. Both states have been targeted to produce potent and selective chemicals to modulate PKs activity. It has been observed that, overall, compounds directed to the inactive conformation have high specificity, while those acting on the active conformation are less specific and generally target several PKs [6].

Due to the fact that PKs are essential components in cellular processes, they are being thoroughly studied and characterized, since, among other activities, they represent attractive targets for drugs against a wide spectrum of diseases, ranging from cancer to cardiovascular problems, diabetes, or immune disorders [5]. Around one-third of current research in drug discovery is directed against the PK superfamily [17]. Kinases are also a key target for therapies against microbial and viral diseases $[18,19]$. In this sense, viral infections rely on virus-host interactions, and it has been described that host cell kinases play crucial roles in every step of the viral life cycle in a wide range of viral species, including members of the Flaviviridae family (flaviviruses and hepaciviruses) [19-22]. In fact, viruses control a vast number of host kinases at different steps along their life cycle [23].

The Flaviviridae is a family of enveloped positive sense single-stranded RNA viruses that comprise more than 60 species grouped into four genera (Table 3).

Table 3. Members of the Flaviviridae family. The four genera, with representative members and genome size corresponding to each genus, are displayed.

\begin{tabular}{ccc}
\hline Genus & Representative Members * & Genome Size (Kb) \\
\hline Flavivirus & YFV, WNV, DENV, ZIKV, TBEV & $9.2-11$ \\
Hepacivirus & HCV & $8.9-10.5$ \\
Pestivirus & BVDV, CSFV & $12.3-13$ \\
Pegivirus & GBV-A, HPgV & $8.9-11.3$ \\
\hline
\end{tabular}

* YFV: yellow fever virus; WNV: West Nile virus; DENV: dengue virus; ZIKV: Zika virus; TBEV: tick borne encephalitis virus; $\mathrm{HCV}$ : hepatitis $\mathrm{C}$ virus; BVDV: bovine viral diarrhea virus; $\mathrm{CSFV}$ : classical swine fever virus; GBV-A: GB virus A; HPgV: human pegivirus type 2.

The genomes of the members of this family are constituted by a single open reading frame (ORF) flanked by $5^{\prime}$ and $3^{\prime}$ untranslated regions (UTRs, Figure 1) [24]. The ORF is translated into a single polyprotein that forms specific secondary structures required for genome translation, virion assembly, cell receptor binding and entry, polyprotein processing, and viral replication. 
A

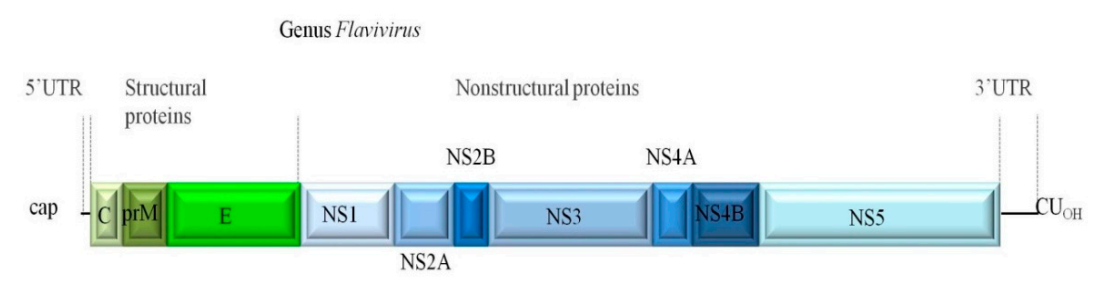

B Genus Hepacivirus

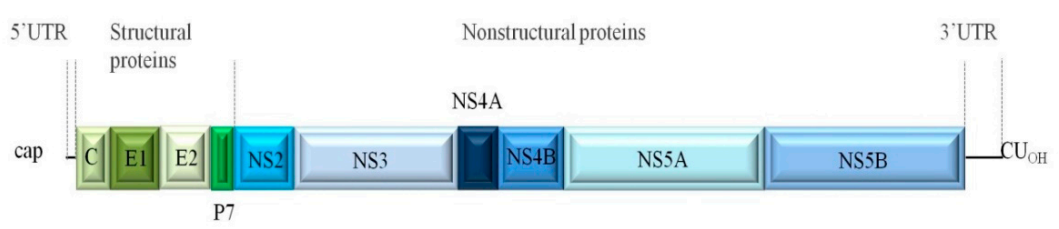

Figure 1. Schematic view of the genomic organization of flaviviruses (A) and hepaciviruses (B). UTR: untranslated region; C: capsid or core protein; prM: pre-membrane protein; p7: polypeptide 7; E: envelope protein; NS: non-structural proteins.

The $5^{\prime}$ and $3^{\prime}$ UTRs are implicated in viral replication and pathogenesis [25]. The capsid (C) protein plays an essential role in viral assembly and replication [26]. The membrane (M) and polypeptide 7 (p7) proteins participate in viral assembly and release of infectious virions $[27,28]$. The envelope (E) protein, the most immunogenic of the viral proteome, is involved in receptor binding, viral entry, and membrane fusion $[27,29]$. The non-structural (NS) proteins are implicated in viral RNA replication, virulence, immunomodulation, viral assembly and modulation of cellular processes [27,29-31].

The Flavivirus genus comprises more than 50 members [32], some of which are human pathogens, causing life-threatening diseases, such as yellow fever, dengue, Japanese encephalitis, West Nile encephalitis, and Zika disease [33]. Flaviviruses are arboviruses (arthropod-borne viruses) mainly transmitted by mosquitoes, and, not surprisingly, due to global climate warming and increasing travelling and trade, their geographic distribution is growing. Many flaviviruses are zoonotic, such as West Nile virus (WNV), with birds as the main natural host $[34,35]$ or Japanese encephalitis virus (JEV), with a cycle involving aquatic birds and pigs as amplifying hosts [36]. Yellow fever virus (YFV) has a sylvatic cycle, which serves to maintain the virus in wild reservoirs between outbreaks in humans [37]. Flaviviruses cause globally relevant epidemics in humans, infecting up to 400 million people annually [33]. Dengue virus (DENV), classified in four serotypes and currently endemic in more than 100 countries [38], can cause a wide spectrum of disease manifestations ranging from a subclinical self-limited infection or a mild febrile illness termed dengue fever, to a life-threatening dengue hemorrhagic fever and dengue shock syndrome, especially after secondary infections with an heterologous serotype [39]. Zika virus (ZIKV) spread throughout the American continent in 2015 causing considerable worldwide social and medical alarm due to its association with congenital disorders [29], such as microcephaly in newborns, or severe neurological manifestations in adults [40]. This led the World Health Organization (WHO) to declare a Public Health Emergency of International Concern (PHEIC) in February 2016 [41]. JEV is a notable cause of encephalitis in Asia [36]. Although most JEV infected people present only subclinical manifestations, a third of symptomatic cases are fatal and almost $50 \%$ of survivors present long-term neurological sequelae [42]. WNV is the worldwide most distributed mosquito-borne flavivirus [27]. Infection is mainly asymptomatic in humans, and when symptoms appear, they can range from a mild febrile disease and non-specific flu-like symptoms to a severe neuroinvasive disease that can also lead to a fatal outcome [27]. YFV is currently endemic in over 40 countries in Africa and the Americas. Individuals infected with YFV can present with a 
wide spectrum of symptoms, ranging from asymptomatic to severe illness with bleeding, jaundice, and death, and, despite vaccination campaigns, over 30,000 deaths are reported each year [43].

The Hepacivirus genus main representative is the hepatitis $\mathrm{C}$ virus (HCV), a major human pathogen that causes liver disease with high risk of developing life-threatening complications, such as liver cirrhosis and hepatocellular carcinoma [44]. Its discoverers, Harvey J. Alter, Charles Rice, and Michael Houghton, were recognized with the 2020 Nobel Prize in Medicine [45]. HCV is mainly transmitted by the parenteral route, although sexual transmission has also been reported [46].

The Pestivirus genus includes economically important members such as bovine viral diarrhea virus (BVDV) and classical swine fever virus (CSFV) [47].

Pegivirus genus shows distant sequence similarity to other members of the family, and infections have not been clearly associated with disease, except for non-Hodgkin's lymphoma [48].

Flaviviridae viral replication is initiated by entering in host cells via receptor-mediated endocytosis. Infection is triggered by binding of virions to their cellular receptor, fusion of the viral envelope with the endosomal host membrane, and subsequent release of the viral genome into the cytosol, which is dependent upon the acidic environment within the lysosome [27,49]. A common feature of Flaviviridae replication is the formation of virus-induced remodeled membrane organelles. They take advantage of host lipids and proteins to generate these virus-induced membrane compartments to assist in replication [50]. Finally, the viral genome is translated into a single polyprotein and processed to produce mature viral proteins, which are transported through the host endoplasmic reticulum (ER)-Golgi secretory pathway to the cell surface for viral release from infected cells (Figure 2).

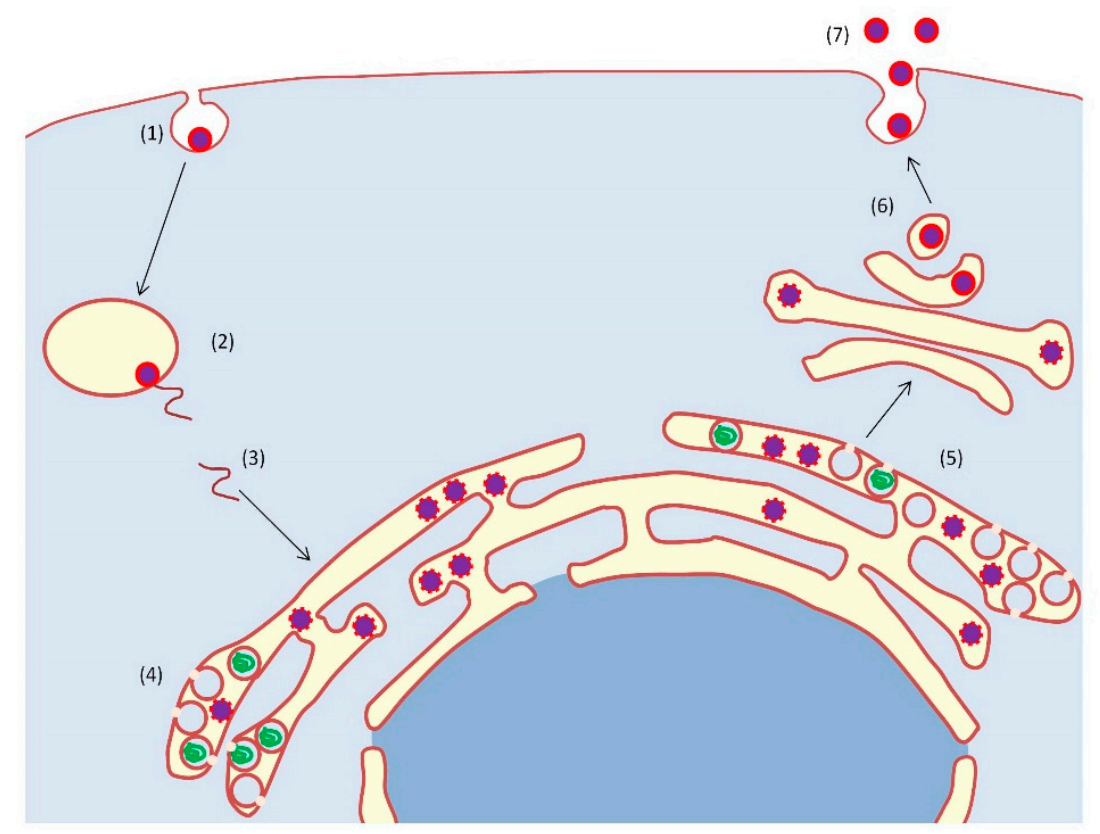

Figure 2. Schematic representation of flaviviral infection. Viral particles enter the cell via receptor-mediated endocytosis (1). The acid environment of endosomes allows viral and endosomal membranes fusion (2), and the subsequent release of viral RNA into the cytosol (3), supporting genome replication and particle biogenesis (4). Viral RNA is translated and processed to produce viral proteins (5), which travel through the Golgi apparatus (6), allowing particle release (7).

Flaviviruses present a worldwide threat to human and animal health, and have the potential to emerge and outbreak in non-endemic geographical regions $[27,51]$, as occurred in the recent Zika virus pandemic [29]. Effective vaccines for humans or animals are only available for a subset of family members, such as tick-borne encephalitis virus (TBEV) YFV, DENV, JEV and, for equids, WNV.

In the quest for antivirals, two different approaches are being applied: searching for compounds directed to viral targets (direct-acting antivirals, (DAAs)), or to cellular components necessary for the 
viral life cycle (host-directed antivirals (HDAs)) [52-55]. In the case of the hepacivirus, HCV, the recent development of highly effective DAAs that cure most infections has represented an outstanding success [56]; however, no specific therapies are available for pestiviruses, pegiviruses, or flaviviruses. In the latter case, palliative treatments focused on alleviating patient symptoms rather than combating the virus are in use [57]. Hence, successful identification of antiviral candidates is considered one of the milestones in the fight against this group of pathogens.

Treatment with DAAs often fails due to the rapid generation of drug-resistant viruses [58], as exemplified by resistance-associated substitutions (RASs, amino acid substitutions in the viral proteins) in the case of $\mathrm{HCV}$ infections [59,60], thus emphasizing the clinical challenge these resistance mutations represent for the management of patients with $\mathrm{HCV}$ and other viral infections [61]. Since almost all members of the Flaviviridae family share common host factors, HDA-based therapies are a feasible solution to overcome these drawbacks [41]. Moreover, targeting host proteins required by different viral species can provide a broad-spectrum therapy. However, HDAs show higher toxicity [62] and smaller efficacy window than DAAs [63].

Studies of the flavivirus replication cycle and interaction with the host cell have provided important understanding of essential aspects of their molecular and cellular biology. The most cost and time effective strategy for the development of broad-spectrum antivirals is drug repurposing. Consequently, pharmacological compounds that target host functions key to the viral life cycle are being tested for activity against multiple viruses [41,64-68]. Chemicals targeting the cellular kinome have been explored as novel potential targets for antiviral drug development. In vitro inhibition of flavivirus and hepacivirus infections has been reported upon the administration of different PK-targeting molecules, both activators and inhibitors, thus indicating their potential therapeutic value in the control of these pathogens. The mechanisms by which members of the Flaviviridae family interact with PKs are diverse. Several cellular pathways have been identified as potentially involved in flaviviral infections. For instance, Src-family kinase (SFK) inhibitors were reported to block DENV infection by altering virus assembly and secretion [69], and modulation of CAMKII activity impacted attachment of JEV to the host cell surface and viral entry [70]. PKA activity affected ZIKV replication at the post-entry stage by affecting negative-sense RNA synthesis, and HCV infection induces PKA activation to enhance virus entry and infectivity [71].

\section{Protein Kinase Targets in the Control of Virus of the Flaviviridae Family}

Pharmacological modulation (both inhibition and activation) of multiple host PKs has been shown to be involved in the regulation of viral infection. Those host PKs most relevant to the control of infection by viruses of the Flaviviridae family are listed in Table 4. 
Table 4. Members of the Flaviviridae family inhibited by PK regulation.

\begin{tabular}{|c|c|c|c|c|c|}
\hline Virus & PK & $\begin{array}{l}\text { Kinase } \\
\text { Group }\end{array}$ & $\begin{array}{l}\text { Kind of PK } \\
\text { Regulation }\end{array}$ & Inhibitor/Activator Used & References \\
\hline \multirow{14}{*}{ DENV } & PKG & AGC & Inhibition & \multirow{2}{*}{$\begin{array}{c}\text { Rp-8-pCPT-cGMPS, TEA } \\
\text { Phorbol 12-myristate 13-acetate } \\
\text { (PMA) }\end{array}$} & [20] \\
\hline & PKC & AGC & Activation & & [72] \\
\hline & MAPKAPK5 & CAMK & Inhibition & SFV785 & [73] \\
\hline & AMPK & CAMK & Activation & PF-06409577 & [74] \\
\hline & JNK & CMGC & Inhibition & SP60025 & [75] \\
\hline & P38 & CMGC & Inhibition & SB003580 & [75-77] \\
\hline & $\mathrm{CDK}$ & CMGC & Inhibition & $\begin{array}{l}\text { Alsterpaullone 2-cyanoethyl, } \\
\text { Cdk1/2 inh III,Cdk2/9 inh }\end{array}$ & {$[78]$} \\
\hline & SFK & TK & Inhibition & AZD0530, Dasatinib, GNF-2 & {$[69,79-81]$} \\
\hline & JAK & TK & Inhibition & WHI-P131 & [82] \\
\hline & BTK & TK & Inhibition & QL-XII-47 & [83] \\
\hline & NTRK1 & TK & Inhibition & SFV785 & [73] \\
\hline & PKM2 & Other & Inhibition & PKM2 inhibitor & [84] \\
\hline & AurKB & Other & Inhibition & ZM 447439 & [85] \\
\hline & NAK & Other & Inhibition & Sunitinib, Erlotinib & [18] \\
\hline \multirow{7}{*}{ ZIKV } & PKA & AGC & Inhibition & \multirow{2}{*}{$\begin{array}{c}\text { PKI 14-22 } \\
\text { PF-06409577 AICAR, Metformin, } \\
\text { GSK621 }\end{array}$} & [71] \\
\hline & AMPK & CAMK & Activation & & {$[74,86]$} \\
\hline & P38 & CMGC & Inhibition & SB203580, SB202190 & {$[71,87]$} \\
\hline & AXL & TK & Inhibition & Cabozantinib, R428 & [88] \\
\hline & BTK & TK & Inhibition & QL-XII-47 & [83] \\
\hline & RIPKs & TKL & Activation & $\mathrm{AP} 1$ & [89] \\
\hline & IRE1 K & Other & Inhibition & KIRA 6 & [90] \\
\hline \multirow{6}{*}{ WNV } & PKC & AGC & Inhibition & Calphostin C, Chelerythrine & {$[91,92]$} \\
\hline & AMPK & CAMK & Activation & PF-06409577 & [74] \\
\hline & SFK & TK & Inhibition & PP2 & [93] \\
\hline & BTK & TK & Inhibition & QL-XII-47 & [83] \\
\hline & EGFR & TK & Inhibition & IFN- $\alpha$ inducible protein 6 & [94] \\
\hline & RIPKs & TKL & Activation & AP1 & [95] \\
\hline \multirow{3}{*}{ YFV } & MAPKAPK5 & CAMK & Inhibition & SFV785 & [73] \\
\hline & CK1 & CK1 & Inhibition & $\mathrm{D} 4776$ & [96] \\
\hline & NTRK1 & TK & Inhibition & SFV785 & [73] \\
\hline \multirow[b]{2}{*}{ JEV } & CHK2 & CAMK & Inhibition & \multirow{2}{*}{$\begin{array}{c}\text { CHK2 inhibitor II } \\
\text { Alsterpaullone 2-cyanoethyl, } \\
\text { Cdk1/2 inh III,Cdk2/9 inh }\end{array}$} & [97] \\
\hline & CDK & CMGC & Inhibition & & [78] \\
\hline \multirow{10}{*}{$\mathrm{HCV}$} & DCLK1 & CAMK & Inhibition & Fluvastatine & [98] \\
\hline & AMPK & CAMK & Activation & Liraglutide & [99] \\
\hline & CKII & CK1 & Inhibition & $\begin{array}{l}\text { 2-dimethylamino-4,5,6,7-tetrabromo- } \\
\text { 1H-benzimidazole }\end{array}$ & [100] \\
\hline & MAPK/ERK & CMGC & Inhibition & PD98059, Sorafenib & [101] \\
\hline & P38/MAPK & CMGC & Inhibition & BmKDfsin 3 & [102] \\
\hline & SRPK & CMGC & Inhibition & SRPIN340 & [103] \\
\hline & EGFR & TK & Inhibition & Erlotinib, Dasatinib & {$[69,104]$} \\
\hline & PKR & Other & Inhibition & HÁ1077 & [105] \\
\hline & NAK & Other & Inhibition & \multirow{2}{*}{$\begin{array}{c}\text { Isothiazolo [5,4-b]pyridine, } \\
\text { Sunitinib, PKC-412 } \\
\text { BX795 }\end{array}$} & [106-108] \\
\hline & TBK1/IKK $\varepsilon$ & Other & Inhibition & & [109] \\
\hline
\end{tabular}

Flaviviridae family infections can be enhanced or diminished upon treatment with PK pharmacological modulators. The effect of drugs regulating PKs, both activators and inhibitors, in infections by members of this family is further described according to the phylogenetic classification of Manning et al. [11]. 


\subsection{The AGC Kinase}

AGC kinase group is named for the initials of its members, kinases related to cAMP-dependent protein kinase 1 (PKA), cGMP-dependent protein kinase (PKG), and protein kinase $\mathrm{C}$ (PKC). The group is formed by serine/threonine protein kinases that share common characteristic structural features, including the presence of a hydrophobic sequence motif close to the C-terminal lobe of the catalytic core [110]. The group comprises more than 60 members classified into 14 subfamilies: PDK1, AKT/PKB, SGK, PKA, PKG, PKC, PKN/PRK, RSK, NDR, MAST, YANK, DMPK, GRK, and SGK494.

Drugs targeting AGC kinases have been shown to be valuable pharmacological candidates for targeting distinct flaviviruses. The PKA inhibitor PKI significantly reduces ZIKV replication by inhibiting the synthesis of viral genomes, producing minimal cytotoxicity on human endothelial cells and astrocytes, highly susceptible to ZIKV infection [71]. The PKG inhibitor Rp-8-pCPT-cGMPS drastically decreases DENV replication in human HEK293T cell culture, while the PKG activator 8-Br-PET-cGMP produces an increase in DENV yield [20]. Similarly, WNV has been reported to upregulate PKCs during infection [91], and the PKC inhibitors calphostin C and chelerythrine have been reported to reduce WNV multiplication [92]. In contrast, in vitro number of DENV viral copies increased upon treatment with the PKC inhibitor bisindolylmaleimide I, whilst the opposite effect was observed in baby hamster kidney (BHK-21) cells treated with the PKC activator phorbol 12-myristate 13-acetate, thus indicating that inhibition of PKC activity promotes DENV replication [72].

\subsection{Calcium Calmodulin Dependent Kinases (CAMK)}

The CAMKs are serine/threonine kinases activated by increases in the concentration of intracellular calcium ions $\left(\mathrm{Ca}^{2+}\right)$. The activity of this group is mainly regulated by the $\mathrm{Ca}^{2+}$ receptor protein calmodulin (CaM). They are classified into two different types: substrate-specific and multi-functional CAMKs. The former can phosphorylate only a specific substrate, while the latter can phosphorylate multiple targets.

A broad antiviral activity against members of the Flaviviridae family has been shown by drugs targeting CAMKs. For instance, SFV785 has selective effects on MAPKAPK5 kinase activity, and has been reported to inhibit DENV and YFV viral yield by altering the co-localization of the structural E protein with the DENV replication complexes. This effect on MAPKAPK5 kinase activity did not inhibit DENV RNA synthesis or translation. [73]. Similarly, inhibition of CHK2 with CHK2 inhibitor II effectively reduced JEV production in a range of human cell lines, such as A549, HEK293T, U87 and BE(2)C [97]. Fluvastatine, an inhibitor of DCLK1, downregulated HCV replication in GS5 cell culture, derived from human hepatoma Huh 7.5 cell line, without exerting any negative effect on cell viability [98]. In addition, silencing of Pim Kinase with siRNA, or pharmacological inhibition with SGI-1776, inhibits HCV at an early entry step when human hepatoma Huh 6 and human primary hepatocyte cell cultures were infected [111].

On the other hand, activation of proteins belonging to the CAMK group has also been reported as being effective. Activation of AMPK with PF-06409577 impaired viral replication in WNV, ZIKV, and DENV infected Vero (monkey) and BHK-21 (hamster) cell lines [74], and other pharmacological activators of AMPK, such as AICAR, metformin, and GSK621 have been described as attenuating ZIKV replication in endothelial cell culture [86]. Likewise, liraglutide, which activates AMPK in an AMPK/TORC2-dependent pathway, inhibits HCV replication in the human hepatoma Huh 7 cell line [99].

\subsection{Casein Kinase 1 (CK1)}

CK1 is a monomeric serine-threonine protein kinase with seven isoforms. Pharmacologic inhibition with d4776 was reported to decrease YFV yield in infected human HEK293 cells [96]; however, inhibition of the CK1 1 isoform with IC261 promotes WNV infection by suppressing the production of type I interferon, either in vitro, after infection in human HEK293 cells, or using an in vivo model, 
since CK1 1 -deficient mice produced less IFN- $\beta$ and were more susceptible to WNV infection [112]. On the other hand, the specific CKII inhibitor, 2-dimethylamino-4,5,6,7-tetrabromo-1H-benzimidazole (DMAT), was shown to disrupt virion biogenesis in human hepatoma Huh 7.5 cell infected with HCV [100]. This inhibitor was described as enhancing HCV genotype 1a production in the same cell line [113], thus revealing that genotype-specific differences should be taken into account for potential future pharmacological use of this compound.

\subsection{CMGC Kinases}

CMGC kinases, such as the AGC group, are named with the initials of family members; cyclin-dependent kinase (CDK), mitogen-activated protein kinase (MAPK), glycogen synthase kinase (GSK), and CDC-like kinase (CLK). This group consists of 63 family members highly conserved in eukaryotic organisms.

Drugs targeting CMGC kinases have been described as antiviral candidates against several flaviviruses, as well as against HCV. In the case of DENV, different studies have highlighted the MAPK/ERK pathway as essential for replication, since DENV infection can directly activate proteins in this pathway, including JNK, p38, NTRK1, MAPKAPK5, and c-src/FYN kinases [84]. JNK and p38 kinase inhibitors were reported to significantly reduce DENV protein synthesis and viral yield in infected monocyte-derived macrophages obtained from human peripheral blood [75]. The p38 inhibitor SB203580 prevented lymphopenia, hematocrit increase, and inflammation in human PBMCs, THP-1, and KU812 cell lines infected with DENV [76], and improved the survival rate in DENV-infected AG129 mice [77]. In vitro inhibition of ZIKV virion production was also observed with this agent in infected human endothelial cells and astrocytes [71] and with the related SB202190 [87]. Furthermore, ZIKV production in human neural cell lines was hindered upon treatment with structurally unrelated CDK inhibitors, such as seliciclib, PHA-690509 [114], and Cdk1/2 inhibitor III [78], which also suppressed DENV and JEV viral propagation in the human hepatoma Huh 7 cell line. Selective inhibition of the MAPK/ERK pathway has also been described to block infectious HCV production in infected human Huh 7.5 cells [101], and the inhibitor BmKDfsin3, obtained from scorpion (Mesobuthus martensii) venom, also decreases HCV replication by downregulation of the p38 MAPK signal pathway in Huh7.5.1 and HEK293T infected cell lines [102]. Finally, an SRPK inhibitor (SRPIN340) suppressed the expression of an HCV subgenomic replicon and the in vitro replication in Huh7 and Huh7.5.1 cell lines of the HCV-JFH1 clone in a dose-dependent manner [103].

\subsection{Tyrosine Kinases (TKs)}

TK phosphorylates almost exclusively on tyrosine residues, whilst most other kinases are selective for serine or threonine. This group is classified into two subtypes, receptor (RTKs) and non-receptor, or cytoplasmic TKs (CTKs), depending on their function in transmembrane signaling, or within the cell mediating signal transduction to the nucleus, respectively. RTKs have transmembrane and extracellular domains, whilst CTKs do not. RTKs primarily transmit extracellular signals into the cell. CTKs are, generally located within the cytoplasm, although often membrane-associated.

TKs have been deeply studied and their involvement in flavivirus replication has been widely reported $[73,83,88,93,104]$. The c-Src/Fyn kinase has been identified as a cellular target in DENV RNA replication. The pharmacological inhibitor saracatinib (AZD0530) inhibits virion assembly of DENV in human Huh7 and HEK293T infected cell lines [69,79]. Likewise, compound 16i, another Src inhibitor, was reported to suppress DENV replication at low micromolar concentrations with no significant toxicity to the host cell [81], thus validating the Src family of TKs as potential drug targets for the development of treatments against DENV infection. Other SFKs are also implicated in DENV infection; Abl inhibitor GNF-2 interferes with DENV replication in human hepatoma Huh-7 and Vero African green monkey kidney infected cells [80]. The involvement of other TKs, such as those acting on the JAK/STAT3 pathway, has been described. JAK2 and JAK3 inhibitors have been reported to reduce DENV-induced phosphorylation of STAT3 and cell migration, as well as production of the chemokines 
IL-8 and RANTES in infected hepatocytes [82]. Likewise, WNV-infected human SK-N-MC and HEK 293 cells treated with the SFK inhibitor PP2 show a decrease in viral titers, whilst there was no effect on intracellular levels of either viral RNA or protein, thus suggesting that the drug has no effect on the early stages of replication [93]. Two inhibitors of AXL phosphorylation, cabozantinib, and R428, significantly impair ZIKV infection of human endothelial cells [88]. TKs have also been related to hepacivirus replication, and the EGFR inhibitor erlotinib inhibited HCV infection in a dose-dependent manner in different cell lines, such as Huh7, Huh7.5.1 cells and primary human hepatocytes [104].

Additionally, diverse TKs have been described as broad-spectrum anti-viral agents. A covalent host BTK inhibitor, QL-XII-47, was reported to inhibit DENV, WNV, and ZIKV in the human Huh 7 cell line [83]. Furthermore, the kinase inhibitor SFV785 was shown to reduce secretion of infectious DENV and YFV virions in Vero and BHK-21 infected cells [73]. Likewise, inhibition of EGFR kinase activity via induction of IFN- $\alpha$ inducible protein 6 (IFI6), an IFN-stimulated gene (ISG), strongly inhibited DENV either in vitro or in vivo in AG129 mice [115], WNV [94], and HCV infection [116], either in vitro or in vivo, in AG129 mice. The wide spectrum TK inhibitor dasatinib was reported to reduce virion assembly in DENV via Fyn kinase in human Huh7 and HEK293T infected cell lines, and to inhibit HCV infection via EphA2 TK in different cell lines, such as Huh7, Huh7.5.1 cells, and primary human hepatocytes $[69,104]$.

\subsection{Tyrosine Kinase-Like (TKL)}

TKL kinases are serine-threonine protein kinases with sequence similarity to TKs, but lacking TK-specific motifs. This is the most recently defined PK group, and families within it are little related to each other. As with TKs, TKL kinases are classified into receptor and non-receptor kinases, and are distributed in eight major families.

The main target among TKL kinases reported as antiviral candidates against flaviviruses are Receptor Interacting Protein Kinases (RIPKs), key mediators of cellular signaling that are essential for the early control of diverse pathogens [117]. Among them, RIPK3 has been described as involved in neuroinflammation and neuronal death during JEV infection, tested either in vitro using neuro2a cells or in vivo, in wild type and RIPK3-/- mice [118]. RIPK3 signaling also restricted viral replication in ZIKV [89] and WNV [95] infections in mice.

\subsection{Other PKs}

There are several families included in the ePKs identified by Manning [11] that lack sequence similarity with the previously described ePK groups, and, thus, they are catalogued in a separate group.

Numerous drugs targeting this heterogeneous group have shown antiviral activity against flaviviruses and HCV infections. For instance, the IRE1 kinase inhibitor KIRA6 reduces viral RNA levels in ZIKV infected the human HeLa cell line [90]. DENV infection has been widely reported to be inhibited by inhibitors of different members of the group, as exemplified by treatment with pyruvate kinase PKM2 inhibitor in DENV-infected U937 cells [84], the AurKB inhibitor ZM 447439 in DENV-infected Huh-7 cells [85], and the NAK family inhibitors, sunitinib and erlotinib (AAK1 and GAK subfamilies inhibitors respectively) in DENV-infected Huh-7 cells [18]. PKR is modulated by cyclophilin A, triggering antiviral responses to inhibit HCV infection in Huh 7 cell line [119], and the PKR2 inhibitor HA1077, also known as fasudil restricted HCV replication in mice [105]. NAK inhibitors also affect HCV assembly, which was disrupted by treatments with erlotinib, dasatinib, or isothiazolo[5,4-b]pyridine (GAK subfamily inhibitors) in Huh 7.5 cells [106], and sunitinib or PKC-412 (AAK1 subfamily inhibitors) tested in Huh7.5 and 293T cell lines [107,108]. Erlotinib and dasatinib are not NAK specific, and inhibit TKs, as mentioned above, although the authors of these studies pointed to GAK inhibition as the cause of HCV inhibition [106]. BX795, a TBK1/IKK $\varepsilon$ inhibitor, showed effects against HCV infection in the Huh 7 cells [109]. As a consequence of its involvement in autophagy, endoplasmic reticulum (ER) stress, and unfolded protein response (UPR), PERK has been associated with apoptosis in JEV infection either in vitro in neuro2a and BHK-21 cells or in vivo in 
BALB/c mice [120], DENV infected canine MDCK cells [121,122], and WNV infected SK-N-MC human neuroblastoma cells [123].

Pharmacological modulation of the STE, RGC, and atypical kinases has yet to be linked to flaviviral infection.

\section{Conclusions}

PKs play central roles in cellular signaling pathways through modulating protein phosphorylation in processes such as cell growth, differentiation, and metabolism. PKs have been deeply studied and characterized and represent attractive targets for drug design against a wide spectrum of disorders, including viral diseases, where, to date, they are the major host target for antiviral pharmacological development. Host cell kinases are involved in every step of the viral life cycle in a wide range of viral species, including those of the Flaviviridae family. The identification of antiviral candidates for flaviviral epidemics is considered one of the milestones in the fight against these health-threatening pathogens. Two different approaches are being applied in the quest for antivirals: DAAs, directly aimed to viral targets, or HDAs that target cellular components essential for the viral life cycle. DAAs often fail due to the rapid emergence of drug-resistant viruses, making HDA-based antivirals a reasonable solution to overcome these drawbacks. Moreover, targeting host proteins required by different viral species may provide a broad-spectrum therapy and, thus, the use of chemicals targeting the cellular kinome has been explored in the search for new antivirals. Nevertheless, and even though there is a plethora of promising studies concerning the inhibition of flavivirus and HCV infection through the use of different PKs-targeting cellular molecules, which could lead to broad-spectrum repurposed or new antivirals, none has yet been approved. Therefore, there is still a long way to go in the study of PK modulators as therapeutic measures to combat these animal and human pathogens.

Author Contributions: Conceptualization, A.-B.B., and J.-C.S.; writing-original draft preparation, A.-B.B.; writing-review and editing, A.-B.B., and J.-C.S. All authors have read and agreed to the published version of the manuscript.

Funding: This research was partially funded by Instituto Nacional de Investigación y Tecnología Agraria y Alimentaria, (INIA) grants RTA-2015-00009-00-00 and E-RTA-2017-00003-C02-01, and Comunidad Autónoma de Madrid grant S2018/BAA-4370 (PLATESA2-CM).

Conflicts of Interest: The authors declare no conflict of interest.

\section{References}

1. The Nobel Prize. Available online: https://www.nobelprize.org/prizes/medicine/1992/press-release/ (accessed on 30 November 2020).

2. Wu, P.; Nielsen, T.E.; Clausen, M.H. FDA-approved small-molecule kinase inhibitors. Trends Pharmacol. Sci. 2015, 36, 422-439. [CrossRef]

3. Samudrala, R. Faculty Opinions recommendation of a comprehensive update of the sequence and structure classification of kinases. Fac. Opin.-Post-Publ. Peer Rev. Biomed. Lit. 2005, 320, 855-881.

4. Genomics, Evolution and Function of Protein Kinases. Available online: http://kinase.com/web/current/ (accessed on 30 November 2020).

5. Shen, K.; Hines, A.C.; Schwarzer, D.; Pickin, K.A.; Cole, P.A. Protein kinase structure and function analysis with chemical tools. Biochim. Biophys. Acta (BBA)-Proteins Proteom. 2005, 1754, 65-78. [CrossRef]

6. Johnson, L.N. Protein kinase inhibitors: Contributions from structure to clinical compounds. Q. Rev. Biophys. 2009, 42, 1-40. [CrossRef] [PubMed]

7. Cohen, P. Protein kinases-The major drug targets of the twenty-first century? Nat. Rev. Drug Discov. 2002, 1, 309-315. [CrossRef] [PubMed]

8. Burnett, G.; Kennedy, E.P. The enzymatic phosphorylation of proteins. J. Biol. Chem. 1954, 211, 969-980. [PubMed]

9. Walsh, D.A.; Perkins, J.P.; Krebs, E.G. An adenosine $3^{\prime}, 5^{\prime}$-monophosphate-dependant protein kinase from rabbit skeletal muscle. J. Biol. Chem. 1968, 243, 3763-3765. 
10. Soderling, T.R.; Hickenbottom, J.P.; Reimann, E.M.; Hunkeler, F.L.; Walsh, D.A.; Krebs, E.G. Inactivation of glycogen synthetase and activation of phosphorylase kinase by muscle adenosine 3',5'-monophosphate-dependent protein kinases. J. Biol. Chem. 1970, 245, 6317-6328.

11. Manning, G.; Whyte, D.B.; Martinez, R.; Hunter, T.; Sudarsanam, S. The protein kinase complement of the human genome. Science 2002, 298, 1912-1934. [CrossRef]

12. Dissmeyer, N.; Schnittger, A. The age of protein kinases. Methods Mol. Biol. 2011, 779, 7-52.

13. Fabbro, D.; Cowan-Jacob, S.W.; Moebitz, H. Ten things you should know about protein kinases: IUPHAR Review 14. Br. J. Pharmacol. 2015, 172, 2675-2700. [CrossRef] [PubMed]

14. De Oliveira, P.S.L.; Ferraz, F.A.N.; Pena, D.A.; Pramio, D.T.; Morais, F.A.; Schechtman, D. Revisiting protein kinase-substrate interactions: Toward therapeutic development. Sci. Signal. 2016, 9, re3. [CrossRef] [PubMed]

15. Roskoski, R. A historical overview of protein kinases and their targeted small molecule inhibitors. Pharmacol. Res. 2015, 100, 1-23. [CrossRef] [PubMed]

16. Roskoski, R. Properties of FDA-approved small molecule protein kinase inhibitors. Pharmacol. Res. 2019, 144, 19-50. [CrossRef] [PubMed]

17. Roskoski, R. Properties of FDA-approved small molecule protein kinase inhibitors: A 2020 update. Pharmacol. Res. 2020, 152, 104609. [CrossRef] [PubMed]

18. Bekerman, E.; Neveu, G.; Shulla, A.; Brannan, J.M.; Pu, S.-Y.; Wang, S.; Xiao, F.; Barouch-Bentov, R.; Bakken, R.R.; Mateo, R.; et al. Anticancer kinase inhibitors impair intracellular viral trafficking and exert broad-spectrum antiviral effects. J. Clin. Investig. 2017, 127, 1338-1352. [CrossRef]

19. Nousiainen, L.; Sillanpää, M.; Jiang, M.; Thompson, J.; Taipale, J.; Julkunen, I. Human kinome analysis reveals novel kinases contributing to virus infection and retinoic-acid inducible gene I-induced type I and type III IFN gene expression. Innate Immun. 2013, 19, 516-530. [CrossRef]

20. Bhattacharya, D.; Best, S.M.; Perera, R.; Kuhn, R.J.; Striker, R. Protein Kinase G Phosphorylates Mosquito-Borne Flavivirus NS5. J. Virol. 2009, 83, 9195-9205. [CrossRef]

21. Colpitts, C.C.; Lupberger, J.; Doerig, C.; Baumert, T.F. Host cell kinases and the hepatitis C virus life cycle. Biochim. Biophys. Acta (BBA)-Proteins Proteom. 2015, 1854, 1657-1662. [CrossRef]

22. Meineke, R.; Rimmelzwaan, G.F.; Elbahesh, H. Influenza Virus Infections and Cellular Kinases. Viruses 2019, 11, 171. [CrossRef]

23. Schor, S.; Einav, S. Repurposing of Kinase Inhibitors as Broad-Spectrum Antiviral Drugs. DNA Cell Biol. 2018, 37, 63-69. [CrossRef] [PubMed]

24. Simmonds, P.; Becher, P.; Bukh, J.; Gould, E.A.; Meyers, G.; Monath, T.; Muerhoff, S.; Pletnev, A.; Rico-Hesse, R.; Smith, D.B.; et al. ICTV Virus Taxonomy Profile: Flaviviridae. J. Gen. Virol. 2017, 98, 2-3. [CrossRef] [PubMed]

25. Liu, Z.-Y.; Qin, C.-F. Structure and function of cis-acting RNA elements of flavivirus. Rev. Med. Virol. 2019, 30, e2092. [CrossRef] [PubMed]

26. Tan, T.Y.; Fibriansah, G.; Lok, S.-M. Capsid protein is central to the birth of flavivirus particles. PLoS Pathog. 2020, 16, e1008542. [CrossRef] [PubMed]

27. Martín-Acebes, M.A.; Saiz, J.C. West Nile virus: A re-emerging pathogen revisited. World J. Virol. 2012, 1, 51-70. [CrossRef] [PubMed]

28. Steinmann, E.; Penin, F.; Kallis, S.; Patel, A.H.; Bartenschlager, R.; Pietschmann, T. Hepatitis C Virus p7 Protein Is Crucial for Assembly and Release of Infectious Virions. PLoS Pathog. 2007, 3, e103. [CrossRef]

29. Saiz, J.C.; Vázquez-Calvo, Á.; Blázquez, A.B.; Merino-Ramos, T.; Escribano-Romero, E.; Martín-Acebes, M.A. Zika Virus: The Latest Newcomer. Front. Microbiol. 2016, 7, 496. [CrossRef]

30. Atoom, A.M.; Taylor, N.G.; Russell, R.S. The elusive function of the hepatitis C virus p7 protein. Virology 2014, 462, 377-387. [CrossRef]

31. Leung, J.Y.; Pijlman, G.P.; Kondratieva, N.; Hyde, J.; MacKenzie, J.M.; Khromykh, A.A. Role of Nonstructural Protein NS2A in Flavivirus Assembly. J. Virol. 2008, 82, 4731-4741. [CrossRef]

32. The ICTV Report on Virus Classification and Taxon Nomenclature. Genus Flavivirus. Available online: https://talk.ictvonline.org/ictv-reports/ictv_online_report/positive-sense-rna-viruses/w/flaviviridae/360/ genus-flavivirus (accessed on 28 November 2020).

33. Pierson, T.C.; Diamond, M.S. The continued threat of emerging flaviviruses. Nat. Microbiol. 2020, 5, 796-812. [CrossRef]

34. De Oya, N.J.; Escribano-Romero, E.; Blázquez, A.-B.; Martín-Acebes, M.A.; Saiz, J.-C. Current Progress of Avian Vaccines against West Nile Virus. Vaccines 2019, 7, 126. [CrossRef] [PubMed] 
35. Wilson, K. Faculty Opinions recommendation of Experimental infection of North American birds with the New York 1999 strain of West Nile virus. Fac. Opin.-Post-Publ. Peer Rev. Biomed. Lit. 2003, 9, 311-322.

36. Satchidanandam, V. Japanese Encephalitis Vaccines. Curr. Treat. Options Infect. Dis. 2020, 1-12. [CrossRef] [PubMed]

37. Pandit, P.; Doyle, M.M.; Smart, K.M.; Young, C.; Drape, G.W.; Kreuder-Johnson, C. Predicting wildlife reservoirs and global vulnerability to zoonotic Flaviviruses. Nat. Commun. 2018, 9, 5425. [CrossRef]

38. World Health Organization. Dengue and Severe Dengue. Available online: https://www.who.int/newsroom/fact-sheets/detail/dengue-and-severe-dengue (accessed on 7 October 2020).

39. King, C.A.; Wegman, A.D.; Endy, T.P. Mobilization and Activation of the Innate Immune Response to Dengue Virus. Front. Cell. Infect. Microbiol. 2020, 10, 574417. [CrossRef]

40. Blázquez, A.-B.; Saiz, J.-C. Neurological manifestations of Zika virus infection. World J. Virol. 2016, 5, 135-143. [CrossRef]

41. Saiz, J.-C. Therapeutic Advances against ZIKV: A Quick Response, a Long Way to Go. Pharmaceuticals 2019, 12, 127. [CrossRef]

42. Su, Q.; Xie, Z.-X.; He, F.; Liu, Z.-C.; Song, X.-J.; Zhao, F.-C.; Li, D.; Che, F.-Y. Adults with severe Japanese encephalitis: A retrospective analysis of 9 cases in Linyi, China. Neurol. Sci. 2020, 1-7. [CrossRef]

43. Bifani, A.M.; Ong, E.Z.; De Alwis, R. Vaccination and Therapeutics: Responding to the Changing Epidemiology of Yellow Fever. Curr. Treat. Options Infect. Dis. 2020, 1-12. [CrossRef]

44. Li, H.-C. Hepatitis C virus: Virology, diagnosis and treatment. World J. Hepatol. 2015, 7, 1377-1389. [CrossRef]

45. The Nobel Prize in Physiology or Medicine 2020. Available online: https://www.nobelprize.org/prizes/ medicine/2020/summary/ (accessed on 25 November 2020).

46. Chan, D.P.; Sun, H.-Y.; Wong, H.T.; Lee, S.-S.; Hung, C.C. Sexually acquired hepatitis C virus infection: A review. Int. J. Infect. Dis. 2016, 49, 47-58. [CrossRef] [PubMed]

47. Ganges, L.; Crooke, H.R.; Bohórquez, J.A.; Postel, A.; Sakoda, Y.; Becher, P.; Ruggli, N. Classical swine fever virus: The past, present and future. Virus Res. 2020, 289, 198151. [CrossRef]

48. The ICTV Report on Virus Classification and Taxon Nomenclature. Genus Pegivirus. Available online: https://talk.ictvonline.org/ictv-reports/ictv_online_report/positive-sense-rna-viruses/w/flaviviridae/ 363/genus-pegivirus (accessed on 28 November 2020).

49. Cloherty, A.P.; Olmstead, A.D.; Ribeiro, C.M.S.; Jean, F. Hijacking of Lipid Droplets by Hepatitis C, Dengue and Zika Viruses-From Viral Protein Moonlighting to Extracellular Release. Int. J. Mol. Sci. 2020, 21, 7901. [CrossRef]

50. Aktepe, T.E.; MacKenzie, J.M. Shaping the flavivirus replication complex: It is curvaceous! Cell. Microbiol. 2018, 20, e12884. [CrossRef] [PubMed]

51. Chong, H.Y.; Leow, C.H.; Majeed, A.B.A. Flavivirus infection-A review of immunopathogenesis, immunological response, and immunodiagnosis. Virus Res. 2019, 274, 197770. [CrossRef] [PubMed]

52. Li, G.; De Clercq, E. Current therapy for chronic hepatitis C: The role of direct-acting antivirals. Antivir. Res. 2017, 142, 83-122. [CrossRef] [PubMed]

53. Martín-Acebes, M.A.; Vázquez-Calvo, Á.; Saiz, J.-C. Lipids and flaviviruses, present and future perspectives for the control of dengue, Zika, and West Nile viruses. Prog. Lipid Res. 2016, 64, 123-137. [CrossRef]

54. Saiz, J.-C.; De Oya, N.J.; Blázquez, A.-B.; Escribano-Romero, E.; Martín-Acebes, M.A. Host-Directed Antivirals: A Realistic Alternative to Fight Zika Virus. Viruses 2018, 10, 453. [CrossRef]

55. Sinigaglia, A.; Peta, E.; Riccetti, S.; Barzon, L. New avenues for therapeutic discovery against West Nile virus. Expert Opin. Drug Discov. 2020, 15, 333-348. [CrossRef]

56. Bartenschlager, R.; Baumert, T.F.; Bukh, J.; Houghton, M.; Lemon, S.M.; Lindenbach, B.D.; Lohmann, V.; Moradpour, D.; Pietschmann, T.; Rice, C.M.; et al. Critical challenges and emerging opportunities in hepatitis $\mathrm{C}$ virus research in an era of potent antiviral therapy: Considerations for scientists and funding agencies. Virus Res. 2018, 248, 53-62. [CrossRef]

57. Kok, W.M. New developments in flavivirus drug discovery. Expert Opin. Drug Discov. 2016, 11, 433-445. [CrossRef] [PubMed]

58. Kumar, N.; Sharma, S.; Kumar, R.; Tripathi, B.N.; Barua, S.; Ly, H.; Rouse, B.T. Host-Directed Antiviral Therapy. Clin. Microbiol. Rev. 2020, 33, e00168-19. [CrossRef] [PubMed]

59. Manns, M.P.; Buti, M.; Gane, E.; Pawlotsky, J.M.; Razavi, H.; Terrault, N.; Younossi, Z. Hepatitis C virus infection. Nat. Rev. Dis. Primers 2017, 3, 17006. [CrossRef] [PubMed] 
60. Pawlotski, J.-M. Hepatitis C Virus Resistance to Direct-Acting Antiviral Drugs in Interferon-Free Regimens. Gastroenterology 2016, 151, 70-86. [CrossRef]

61. Colpitts, C.C.; Baumert, T.F. Addressing the Challenges of Hepatitis C Virus Resistance and Treatment Failure. Viruses 2016, 8, 226. [CrossRef]

62. Kaufmann, S.H.E.; Dorhoi, A.; Hotchkiss, R.S.; Bartenschlager, R. Host-directed therapies for bacterial and viral infections. Nat. Rev. Drug Discov. 2018, 17, 35-56. [CrossRef]

63. Troost, B.; Smit, J.M. Recent advances in antiviral drug development towards dengue virus. Curr. Opin. Virol. 2020, 43, 9-21. [CrossRef]

64. Radi, M. Drug repurposing approaches to fight Dengue virus infection and related diseases. Front. Biosci. 2018, 23, 997-1019. [CrossRef]

65. Martín-Acebes, M.A.; De Oya, N.J.; Saiz, J.-C. Lipid Metabolism as a Source of Druggable Targets for Antiviral Discovery against Zika and Other Flaviviruses. Pharmaceuticals 2019, 12, 97. [CrossRef]

66. Mendes, É.A.; de Pilger, D.R.; Nastri, A.C.; de Mello Malta, F.; dos Santos Pascoalino, B.; D'Albuquerque, L.A.; Balan, A.; de Freitas, L.H., Jr.; Durigon, E.L.; Carrilho, F.J.; et al. Sofosbuvir inhibits yellow fever virus in vitro and in patients with acute liver failure. Ann. Hepatol. 2019, 18, 816-824. [CrossRef]

67. Cusinato, J.; Cau, Y.; Calvani, A.M.; Mori, M. Repurposing drugs for the management of COVID-19. Expert Opin. Ther. Patents 2020. [CrossRef] [PubMed]

68. Kotta, S.; Aldawsari, H.M.; Badr-Eldin, S.M.; Alhakamy, N.A.; Md, S.; Nair, A.B.; Deb, P.K. Combating the Pandemic COVID-19: Clinical Trials, Therapies and Perspectives. Front. Mol. Biosci. 2020, 7, 606393. [CrossRef] [PubMed]

69. De Wispelaere, M.; Lacroix, A.J.; Yang, P.L. The Small Molecules AZD0530 and Dasatinib Inhibit Dengue Virus RNA Replication via Fyn Kinase. J. Virol. 2013, 87, 7367-7381. [CrossRef] [PubMed]

70. Felicetti, T.; Manfroni, G.; Cecchetti, V.; Cannalire, R. Broad-Spectrum Flavivirus Inhibitors: A Medicinal Chemistry Point of View. ChemMedChem 2020. [CrossRef] [PubMed]

71. Cheng, F.; Da Silva, S.R.; Huang, I.-C.; Jung, J.U.; Gao, S.-J. Suppression of Zika virus infection and replication in endothelial cells and astrocytes by PKA inhibitor PKI 14-22. J. Virol. 2017, 92, JVI.02019-17. [CrossRef] [PubMed]

72. Noppakunmongkolchai, W.; Poyomtip, T.; Jittawuttipoka, T.; Luplertlop, N.; Sakuntabhai, A.; Chimnaronk, S.; Jirawatnotai, S.; Tohtong, R. Inhibition of protein kinase C promotes dengue virus replication. Virol. J. 2016, 13,1-13. [CrossRef]

73. Anwar, A.; Hosoya, T.; Leong, K.M.; Onogi, H.; Okuno, Y.; Hiramatsu, T.; Koyama, H.; Suzuki, M.; Hagiwara, M.; Garcia-Blanco, M.A. The Kinase Inhibitor SFV785 Dislocates Dengue Virus Envelope Protein from the Replication Complex and Blocks Virus Assembly. PLoS ONE 2011, 6, e23246. [CrossRef]

74. De Oya, N.J.; Blázquez, A.-B.; Casas, J.; Saiz, J.-C.; Martín-Acebes, M.A. Direct Activation of Adenosine Monophosphate-Activated Protein Kinase (AMPK) by PF-06409577 Inhibits Flavivirus Infection through Modification of Host Cell Lipid Metabolism. Antimicrob. Agents Chemother. 2018, 62. [CrossRef]

75. Ceballos-Olvera, I.; Chávez-Salinas, S.; Medina, F.; Ludert, J.E.; Del Ángel, R.M. JNK phosphorylation, induced during dengue virus infection, is important for viral infection and requires the presence of cholesterol. Virology 2010, 396, 30-36. [CrossRef]

76. Fu, Y.; Yip, A.; Seah, P.G.; Blasco, F.; Shi, P.-Y.; Hervé, M. Modulation of inflammation and pathology during dengue virus infection by p38 MAPK inhibitor SB203580. Antivir. Res. 2014, 110, 151-157. [CrossRef]

77. Sreekanth, G.P.; Chuncharunee, A.; Sirimontaporn, A.; Panaampon, J.; Noisakran, S.; Yenchitsomanus, P.-T.; Limjindaporn, T. SB203580 Modulates p38 MAPK Signaling and Dengue Virus-Induced Liver Injury by Reducing MAPKAPK2, HSP27, and ATF2 Phosphorylation. PLoS ONE 2016, 11, e0149486. [CrossRef] [PubMed]

78. Tokunaga, M.; Miyamoto, Y.; Suzuki, T.; Otani, M.; Inuki, S.; Esaki, T.; Nagao, C.; Mizuguchi, K.; Ohno, H.; Yoneda, Y.; et al. Novel anti-flavivirus drugs targeting the nucleolar distribution of core protein. Virology 2020, 541, 41-51. [CrossRef] [PubMed]

79. Chu, J.J.H.; Yang, P.L. c-Src protein kinase inhibitors block assembly and maturation of dengue virus. Proc. Natl. Acad. Sci. USA 2007, 104, 3520-3525. [CrossRef] [PubMed]

80. Clark, M.J.; Miduturu, C.; Schmidt, A.G.; Zhu, X.; Pitts, J.D.; Wang, J.; Potisopon, S.; Zhang, J.; Wojciechowski, A.; Chu, J.J.H.; et al. GNF-2 Inhibits Dengue Virus by Targeting Abl Kinases and the Viral E Protein. Cell Chem. Biol. 2016, 23, 443-452. [CrossRef] 
81. Vincetti, P.; Caporuscio, F.; Kaptein, S.; Gioiello, A.; Mancino, V.; Suzuki, Y.; Yamamoto, N.; Crespan, E.; Lossani, A.; Maga, G.; et al. Discovery of Multitarget Antivirals Acting on Both the Dengue Virus NS5-NS3 Interaction and the Host Src/Fyn Kinases. J. Med. Chem. 2015, 58, 4964-4975. [CrossRef]

82. Tsai, Y.-T.; Chen, Y.-H.; Chang, D.-M.; Chen, P.-C.; Lai, J.-H. Janus kinase/signal transducer and activator of transcription 3 signaling pathway is crucial in chemokine production from hepatocytes infected by dengue virus. Exp. Biol. Med. 2011, 236, 1156-1165. [CrossRef]

83. De Wispelaere, M.; Carocci, M.; Liang, Y.; Liu, Q.; Sun, E.; Vetter, M.L.; Wang, J.; Gray, N.S.; Yang, P.L. Discovery of host-targeted covalent inhibitors of dengue virus. Antivir. Res. 2017, 139, 171-179. [CrossRef]

84. Wongtrakul, J.; Thongtan, T.; Pannengpetch, S.; Wikan, N.; Kantamala, D.; Kumrapich, B.; Suwan, W.; Smith, D.R. Phosphoproteomic analysis of dengue virus infected U937 cells and identification of pyruvate kinase M2 as a differentially phosphorylated phosphoprotein. Sci. Rep. 2020, 10, 1-13. [CrossRef]

85. Pérez-Olais, J.H.; Ruíz-Jiménez, F.; Calderon-Garcia, E.J.; De Jesús-González, L.A.; Hernández-Rivas, R.; Del Ángel, R.M.; De Jesus-González, L.A. The activity of Aurora kinase B is required for dengue virus release. Virus Res. 2019, 274, 197777. [CrossRef]

86. Singh, S.; Singh, P.K.; Suhail, H.; Arumugaswami, V.; Pellett, P.E.; Giri, S.; Kumar, A. AMP-Activated Protein Kinase Restricts Zika Virus Replication in Endothelial Cells by Potentiating Innate Antiviral Responses and Inhibiting Glycolysis. J. Immunol. 2020, 204, 1810-1824. [CrossRef]

87. Zhu, S.; Luo, H.; Liu, H.; Ha, Y.; Mays, E.R.; Lawrence, R.E.; Winkelmann, E.R.; Barrett, A.D.; Smith, S.B.; Wang, M.; et al. p38MAPK plays a critical role in induction of a pro-inflammatory phenotype of retinal Müller cells following Zika virus infection. Antivir. Res. 2017, 145, 70-81. [CrossRef] [PubMed]

88. Liu, S.; DeLalio, L.J.; Isakson, B.E.; Wang, T.T. AXL-Mediated Productive Infection of Human Endothelial Cells by Zika Virus. Circ. Res. 2016, 119, 1183-1189. [CrossRef] [PubMed]

89. Daniels, B.P.; Kofman, S.B.; Smith, J.R.; Norris, G.T.; Snyder, A.G.; Kolb, J.P.; Gao, X.; Locasale, J.W.; Martinez, J.; Gale, M.; et al. The Nucleotide Sensor ZBP1 and Kinase RIPK3 Induce the Enzyme IRG1 to Promote an Antiviral Metabolic State in Neurons. Immunity 2019, 50, 64-76.e4. [CrossRef] [PubMed]

90. Kolpikova, E.P.; Tronco, A.R.; Hartigh, A.B.D.; Jackson, K.J.; Iwawaki, T.; Fink, S.L. IRE1 $\alpha$ Promotes Zika Virus Infection via XBP1. Viruses 2020, 12, 278. [CrossRef]

91. Besson, B.; Basset, J.; Gatellier, S.; Chabrolles, H.; Chaze, T.; Hourdel, V.; Matondo, M.; Pardigon, N.; Choumet, V. Comparison of a human neuronal model proteome upon Japanese encephalitis or West Nile Virus infection and potential role of mosquito saliva in neuropathogenesis. PLoS ONE 2020, 15, e0232585. [CrossRef]

92. Blázquez, A.-B.; Vázquez-Calvo, Á.; Martín-Acebes, M.A.; Saiz, J.-C. Pharmacological Inhibition of Protein Kinase C Reduces West Nile Virus Replication. Viruses 2018, 10, 91. [CrossRef]

93. Hirsch, A.J.; Medigeshi, G.R.; Meyers, H.L.; DeFilippis, V.; Früh, K.; Briese, T.; Lipkin, W.I.; Nelson, J.A. The Src Family Kinase c-Yes Is Required for Maturation of West Nile Virus Particles. J. Virol. 2005, 79, 11943-11951. [CrossRef]

94. Li, J.; Ding, S.C.; Cho, H.; Chung, B.C.; Gale, M.; Chanda, S.K.; Diamond, M.S. A Short Hairpin RNA Screen of Interferon-Stimulated Genes Identifies a Novel Negative Regulator of the Cellular Antiviral Response. mBio 2013, 4, e00385-13. [CrossRef]

95. Daniels, B.P.; Snyder, A.G.; Olsen, T.M.; Orozco, S.; Oguin, T.H., 3rd; Tait, S.W.G.; Martinez, J.; Gale, M., Jr.; Loo, Y.M.; Oberst, A. RIPK3 Restricts Viral Pathogenesis via Cell Death-Independent Neuroinflammation. Cell 2017, 169, 301-313.e11. [CrossRef]

96. Bhattacharya, D.; Ansari, I.H.; Striker, R. The flaviviral methyltransferase is a substrate of Casein Kinase 1. Virus Res. 2009, 141, 101-104. [CrossRef]

97. Chan, Y.-L.; Liao, C.-L.; Lin, Y.-L. Human Kinase/Phosphatase-Wide RNAi Screening Identified Checkpoint Kinase 2 as a Cellular Factor Facilitating Japanese Encephalitis Virus Infection. Front. Cell. Infect. Microbiol. 2018, 8, 142. [CrossRef] [PubMed]

98. Ali, N.; Allam, H.; Bader, T.; May, R.; Basalingappa, K.M.; Berry, W.L.; Chandrakesan, P.; Qu, D.; Weygant, N.; Bronze, M.S.; et al. Fluvastatin interferes with hepatitis $C$ virus replication via microtubule bundling and a doublecortin-like kinase-mediated mechanism. PLoS ONE 2013, 8, e80304. [CrossRef]

99. Lee, M.; Chen, W.-C.; Hsu, W.-H.; Chen, S.-C.; Lee, J.-C. Liraglutide Inhibits Hepatitis C Virus Replication Through an AMP Activated Protein Kinase Dependent Mechanism. Int. J. Mol. Sci. 2019, 20, 4569. [CrossRef] 
100. Tellinghuisen, T.L.; Foss, K.L.; Treadaway, J. Regulation of Hepatitis C Virion Production via Phosphorylation of the NS5A Protein. PLoS Pathog. 2008, 4, e1000032. [CrossRef]

101. Menzel, N.; Fischl, W.; Hueging, K.; Bankwitz, D.; Frentzen, A.; Haid, S.; Gentzsch, J.; Kaderali, L.; Bartenschlager, R.; Pietschmann, T. MAP-Kinase Regulated Cytosolic Phospholipase A2 Activity Is Essential for Production of Infectious Hepatitis C Virus Particles. PLoS Pathog. 2012, 8, e1002829. [CrossRef] [PubMed]

102. Cheng, Y.; Sun, F.; Li, S.; Gao, M.; Wang, L.; Sarhan, M.; Abdel-Rahman, M.A.; Li, W.; Kwok, H.F.; Wu, Y.; et al. Inhibitory Activity of a Scorpion Defensin BmKDfsin3 against Hepatitis C Virus. Antibiotics 2020, 9, 33. [CrossRef] [PubMed]

103. Karakama, Y.; Sakamoto, N.; Itsui, Y.; Nakagawa, M.; Tasaka-Fujita, M.; Nishimura-Sakurai, Y.; Kakinuma, S.; Oooka, M.; Azuma, S.; Tsuchiya, K.; et al. Inhibition of Hepatitis C Virus Replication by a Specific Inhibitor of Serine-Arginine-Rich Protein Kinase. Antimicrob. Agents Chemother. 2010, 54, 3179-3186. [CrossRef]

104. Lupberger, J.; Zeisel, M.B.; Xiao, F.; Thumann, C.; Fofana, I.; Zona, L.; Davis, C.; Mee, C.J.; Turek, M.; Gorke, S.; et al. EGFR and EphA2 are host factors for hepatitis $C$ virus entry and possible targets for antiviral therapy. Nat. Med. 2011, 17, 589-595. [CrossRef]

105. Lee, S.-H.; Moon, J.-S.; Pak, B.-Y.; Kim, G.-W.; Lee, W.; Cho, H.; Kim, S.; Kim, S.-J.; Oh, J.-W. HA1077 displays synergistic activity with daclatasvir against hepatitis $C$ virus and suppresses the emergence of NS5A resistance-associated substitutions in mice. Sci. Rep. 2018, 8, 1-13. [CrossRef]

106. Kovackova, S.; Chang, L.; Bekerman, E.; Neveu, G.; Barouch-Bentov, R.; Chaikuad, A.; Heroven, C.; Šála, M.; De Jonghe, S.; Knapp, S.; et al. Selective Inhibitors of Cyclin G Associated Kinase (GAK) as Anti-Hepatitis C Agents. J. Med. Chem. 2015, 58, 3393-3410. [CrossRef]

107. Neveu, G.; Ziv-Av, A.; Barouch-Bentov, R.; Berkerman, E.; Mulholland, J.; Einav, S.; DeWitt, W.S.; Emerson, R.O.; Lindau, P.; Vignali, M.; et al. AP-2-Associated Protein Kinase 1 and Cyclin G-Associated Kinase Regulate Hepatitis C Virus Entry and Are Potential Drug Targets. J. Virol. 2015, 89, 4387-4404. [CrossRef] [PubMed]

108. Zeisel, M.B.; Crouchet, E.; Baumert, T.F.; Schuster, C. Host-Targeting Agents to Prevent and Cure Hepatitis C Virus Infection. Viruses 2015, 7, 5659-5685. [CrossRef] [PubMed]

109. Vazquez, C.; Tan, C.Y.; Horner, S.M. Hepatitis C Virus Infection Is Inhibited by a Noncanonical Antiviral Signaling Pathway Targeted by NS3-NS4A. J. Virol. 2019, 93. [CrossRef] [PubMed]

110. Leroux, A.E.; Schulze, J.O.; Biondi, R.M. AGC kinases, mechanisms of regulation and innovative drug development. Semin. Cancer Biol. 2018, 48, 1-17. [CrossRef]

111. Park, C.; Min, S.; Park, E.-M.; Lim, Y.-S.; Kang, S.; Suzuki, T.; Shin, E.-C.; Hwang, S.B. Pim Kinase Interacts with Nonstructural 5A Protein and Regulates Hepatitis C Virus Entry. J. Virol. 2015, 89, 10073-10086. [CrossRef]

112. Zhou, Y.; He, C.; Yan, D.; Liu, F.; Liu, H.; Chen, J.; Cao, T.; Zuo, M.; Wang, P.; Ge, Y.; et al. The kinase CK1varepsilon controls the antiviral immune response by phosphorylating the signaling adaptor TRAF3. Nat. Immunol. 2016, 17, 397-405. [CrossRef]

113. Kim, S.; Jin, B.; Choi, S.H.; Han, K.-H.; Ahn, S.H. Casein Kinase II Inhibitor Enhances Production of Infectious Genotype 1a Hepatitis C Virus (H77S). PLoS ONE 2014, 9, e113938. [CrossRef]

114. Xu, M.; Lee, E.M.; Wen, Z.; Cheng, Y.; Huang, W.-K.; Qian, X.; Tcw, J.; Kouznetsova, J.; Ogden, S.C.; Hammack, C.; et al. Identification of small-molecule inhibitors of Zika virus infection and induced neural cell death via a drug repurposing screen. Nat. Med. 2016, 22, 1101-1107. [CrossRef]

115. Schoggins, J.W.; Dorner, M.; Feulner, M.; Imanaka, N.; Murphy, M.Y.; Ploss, A.; Rice, C. Dengue reporter viruses reveal viral dynamics in interferon receptor-deficient mice and sensitivity to interferon effectors in vitro. Proc. Natl. Acad. Sci. USA 2012, 109, 14610-14615. [CrossRef]

116. Meyer, K.; Kwon, Y.-C.; Liu, S.; Hagedorn, C.H.; Ray, R.B.; Ray, R. Interferon- $\alpha$ inducible protein 6 impairs EGFR activation by CD81 and inhibits hepatitis C virus infection. Sci. Rep. 2015, 5, 9012. [CrossRef]

117. Eng, V.V.; Wemyss, M.A.; Pearson, J.S. The diverse roles of RIP kinases in host-pathogen interactions. Semin. Cell Dev. Biol. 2020. [CrossRef] [PubMed]

118. Bian, P.; Ye, C.; Zheng, X.; Luo, C.; Yang, J.; Li, M.; Wang, Y.; Yang, J.; Zhou, Y.; Zhang, F.; et al. RIPK3 Promotes JEV Replication in Neurons via Downregulation of IFI44L. Front. Microbiol. 2020, 11, 368. [CrossRef] [PubMed]

119. Colpitts, C.C.; Ridewood, S.; Schneiderman, B.; Warne, J.; Tabata, K.; Ng, C.F.; Bartenschlager, R.; Selwood, D.L.; Towers, G.J. Hepatitis C virus exploits cyclophilin A to evade PKR. eLife 2020, 9, e52237. [CrossRef] [PubMed] 
120. Wang, Q.; Xin, X.; Wang, T.; Wan, J.; Ou, Y.; Yang, Z.; Yu, Q.; Zhu, L.; Guo, Y.; Wu, Y.; et al. Japanese Encephalitis Virus Induces Apoptosis and Encephalitis by Activating the PERK Pathway. J. Virol. 2019, 93. [CrossRef]

121. Datan, E.; Roy, S.G.; Germain, G.; Zali, N.; McLean, J.E.; Golshan, G.; Harbajan, S.; Lockshin, R.A.; Zakeri, Z. Dengue-induced autophagy, virus replication and protection from cell death require ER stress (PERK) pathway activation. Cell Death Dis. 2016, 7, e2127. [CrossRef]

122. Peña, J.; Harris, E. Dengue Virus Modulates the Unfolded Protein Response in a Time-dependent Manner. J. Biol. Chem. 2011, 286, 14226-14236. [CrossRef]

123. Medigeshi, G.R.; Lancaster, A.M.; Hirsch, A.J.; Briese, T.; Lipkin, W.I.; DeFilippis, V.; Früh, K.; Mason, P.W.; Nikolich-Zugich, J.; Nelson, J.A. West Nile Virus Infection Activates the Unfolded Protein Response, Leading to CHOP Induction and Apoptosis. J. Virol. 2007, 81, 10849-10860. [CrossRef]

Publisher's Note: MDPI stays neutral with regard to jurisdictional claims in published maps and institutional affiliations.

(C) 2020 by the authors. Licensee MDPI, Basel, Switzerland. This article is an open access article distributed under the terms and conditions of the Creative Commons Attribution (CC BY) license (http://creativecommons.org/licenses/by/4.0/). 